\title{
Writing prescriptions by palliative care nurses in Poland
}

\begin{abstract}
Introduction: The introduction of new permissions, in the field of prescribing medicines and medical devices for nurses and midwives in Poland, took place at the beginning of 2014. Then a draft amendment to the Act on the profession of nurse and midwife was presented by the Ministry of Health. The study aimed to explore nurses' opinions about the possibility of prescribing drugs and medical devices.

Material and methods: The study was conducted in the period from January to February 2020 among 100 nurses related to palliative care from all over Poland. An own survey questionnaire consisting of 23 questions was used.

Results: All participants responded to the questionnaire (response rate $=100 \%$ ). More than half of the respondents $(55 \%)$ write prescriptions in palliative nursing practice. Most respondents $(89 \%)$ confirmed that the obtained right to prescribe increases the prestige of the nursing profession and $83 \%$ of respondents believed that this right contributes to an improvement of the quality of medical services. A total of $57 \%$ of surveyed participants indicated the need to expand a list of drugs that could be prescribed by palliative care nurses.

Conclusions: Most of the surveyed nurses expressed views that the obtained possibility to prescribe drugs increases the prestige of the nursing profession and that this right contributes to the improvement of the quality of medical services provided by nurses.
\end{abstract}

Palliat Med Pract 2021; 15, 2: 127-134

Key words: nurse, palliative care, prescriptions, drugs, medical products

\section{Introduction}

The introduction of a new law, in the field of prescribing medicines and medical devices for nurses and midwives in Poland, took place at the beginning of 2014. Then a draft amendment to the Act on the profession of nurse and midwife was presented by the Ministry of Health. On January 1, 2016, Polish nurses and midwives were empowered to prescribe drugs and foodstuffs for particular nutritional uses, as well as a wide range of medical devices, which advances nursing practice in our country [1-3].

Depending on the level of education, nurses and midwives can prescribe medicines containing specific active substances and issue orders for medical products. Nurses and midwives with a master's degree or a specialist in the field of nursing have the broadest competencies because they can independently pre-

\section{Address for correspondence:}

Bożena Kosińska

University of Management in Częstochowa

ul. Krychnowicka 1, 26-600 Radom, Poland

tel.: 509037 118, e-mail: bozko@vp.pl

Palliative Medicine in Practice $2021 ; 15,2,127-134$

Copyright (C) Via Medica, ISSN 2545-0425, e-ISSN: 2545-1359

DOI: $10.5603 / \mathrm{PMPI} .2021 .0008$

This article is available in open access under Creative Common Attribution-Non-Commercial-No Derivatives 4.0 International (CC BY-NC-ND 4.0) license, allowing to download articles and share them with others as long as they credit the authors and the publisher, but without permission to change them in any way or use them commercially. 
scribe drugs and medical products specified in the regulation of the Minister of Health of 18 January 2018 (Journal of Laws 2018, item 299), and also issue referrals for diagnostic tests. Prescriptions as a continuation of the treatment planned by a doctor can be issued by bachelor's degree nurses and midwives. To acquire new rights, both groups are required to complete a specialist course in this field. From the 2017/2018 academic year, students gain knowledge in this field during education, in nursing and midwifery schools, both first and second degree and specialization training. These people do not need any additional education to be eligible to write prescriptions $[1,4-6]$.

At the moment, nurses have the right to prescribe drugs such as antiemetics - ondansetron, aprepitant, thiethylperazine; topical antifungals (nystatin - forms for application to the skin and mucous membranes); metronidazole - forms for application to the skin and mucous membranes; gynaecological intravaginal antifungals (e.g. nystatin, natamycin, clotrimazole), metronidazole; antibiotics: amoxicillin, doxycycline, phenoxymethylpenicillin; bacteriostats: trimethoprim, local anaesthetics: lidocaine; analgesics: tramadol and tramadol with paracetamol - oral and rectal forms; anxiolytics: hydroxyzine [4].

The new solutions of writing the prescriptions are broadly reflected in the daily activities of the palliative care nurse. These competencies must be used as a great opportunity that helps to strengthen the prestige of the nursing profession and improves the quality of medical services, not as an additional workload or professionalism attributed only to the doctor $[7,8]$. Hospice care nurses are partners, and often leaders of the medical team. They are in daily contact with a sick and dying person, and when the general condition of the patient changes quickly, they often provide services on their own. The study aimed to explore nurses' opinions about the possibility of prescribing drugs and medical devices.

\section{Material and methods}

The research was carried out in two stages. The first stage was a pilot study in which 15 nurses took part in May 2019. The second stage was carried out in a group of 100 nurses from all over Poland related to palliative care in the period from January to February 2020. The research was anonymous, and the questionnaire consisted of demographic details and 15 thematic questions (see appendix). For the presented article, the following questions were selected: $1-4$, and 13-15. The completed questionnaire constituted consent to participate in the survey. The research was conducted online (60 questionnaires) and in printed forms (40 questionnaires). As the study was not a research experiment an ethical approval was not required.

Statistical analysis was conducted using the PQStat statistical package, version 1.8.0.324. The relationships between the responses were analysed using the Fisher's exact test. The test probability at the level of $p<0.05$ was assumed as significant.

\section{Results}

All participants responded to the questionnaire (response rate $=100 \%$ ). The majority of the surveyed population were nurses over 41 years old $(75 \%)$ and the least numerous group consisted of nurses aged 20-30 (7\%). Higher education (master's degree) was declared by $51 \%$ of the respondents, moreover, $24 \%$ were during the master studies in nursing. Another $12 \%$ had higher education - a bachelor's degree. Only $13 \%$ of respondents had secondary education. Most of the respondents, i.e., $84 \%$ completed the specialization, while $49 \%$ completed a qualification course in various fields of nursing. Among the respondents, almost a quarter of them worked in palliative care for 6 to 10 years, slightly fewer respondents $(20 \%)$ worked in palliative care for $21-25$ years. The smallest number of respondents had work experience in palliative care over 26 years (12\%) (Table 1).

More than half of the respondents $(55 \%)$ write prescriptions in palliative nursing practice (Fig. 1). Most respondents (89\%) confirm that the obtained right to prescribe drugs and write prescriptions increases the prestige of the nursing profession (Fig. 2). A total of $83 \%$ of respondents believe that this right contributes to the improvement of the quality of medical services (Fig. 3). A total of $57 \%$ of surveyed indicated the need to expand the list of drugs that could be prescribed by palliative care nurses (Fig. 4). The proposed drugs that would be helpful in the daily professional activity of palliative care nurses are shown in Figure 5 . The barriers to issuing the prescriptions by nurses are shown in Figure 6.

More nurses with higher education level have completed a specialist course in writing prescriptions (Table 2). To a question: Have you ever encountered a refusal to fulfil a prescription issued by a nurse by a pharmacist, over one-third of respondents met with a pharmacist's refusal to fill prescription issued by nurses (Table 3). Two most common reasons for refusing to fulfil prescriptions are pharmacist insufficient knowledge of nurses right to prescribe and pharmacist lack of knowledge about the list of drugs that can be prescribed by nurses and midwives (Table 4). 
Table 1. Sociodemographic data of the respondents

\begin{tabular}{|c|c|c|}
\hline \multicolumn{3}{|l|}{ Age } \\
\hline 20-30 years old & 7 & $7 \%$ \\
\hline $31-40$ years old & 18 & $18 \%$ \\
\hline $41-50$ years old & 46 & $46 \%$ \\
\hline Over 51 years old & 29 & $29 \%$ \\
\hline \multicolumn{3}{|l|}{ Education } \\
\hline $\begin{array}{l}\text { Secondary (medical high school, medical } \\
\text { vocational school) }\end{array}$ & 13 & $13 \%$ \\
\hline Higher first degree - Bachelor of Nursing & 12 & $12 \%$ \\
\hline $\begin{array}{l}\text { Higher second degree - Master of Nur- } \\
\text { sing }\end{array}$ & 51 & $51 \%$ \\
\hline $\begin{array}{l}\text { During second degree - Master of Nur- } \\
\text { sing }\end{array}$ & 24 & $24 \%$ \\
\hline \multicolumn{3}{|c|}{$\begin{array}{l}\text { Completed postgraduate education (multiple } \\
\text { answers possible) }\end{array}$} \\
\hline Specialization & 84 & $84 \%$ \\
\hline Qualification course & 49 & $49 \%$ \\
\hline Different type of course & 15 & $15 \%$ \\
\hline \multicolumn{3}{|l|}{ Work experience in palliative care } \\
\hline$<5$ years & 15 & $15 \%$ \\
\hline $6-10$ years & 23 & $23 \%$ \\
\hline $11-15$ years & 17 & $17 \%$ \\
\hline $16-20$ years & 13 & $13 \%$ \\
\hline $21-25$ years & 20 & $20 \%$ \\
\hline $26-30$ years & 8 & $8 \%$ \\
\hline$>30$ years & 4 & $4 \%$ \\
\hline \multicolumn{3}{|l|}{ Place of residence } \\
\hline City & 63 & $63 \%$ \\
\hline Village & 37 & $37 \%$ \\
\hline
\end{tabular}

Place of work in palliative care (multiple answers possible)

\begin{tabular}{|lll|}
\hline Home hospice/home palliative care team & 79 & $79 \%$ \\
\hline Palliative medicine outpatient clinic & 20 & $20 \%$ \\
\hline Stationary hospice or palliative care unit & 20 & $20 \%$ \\
\hline
\end{tabular}

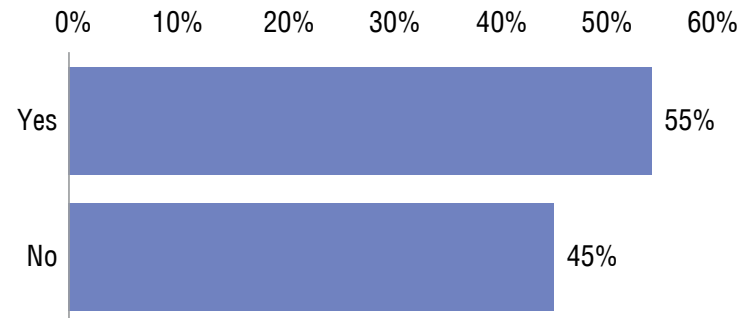

Figure 1. Do you write prescriptions in your nursing practice?

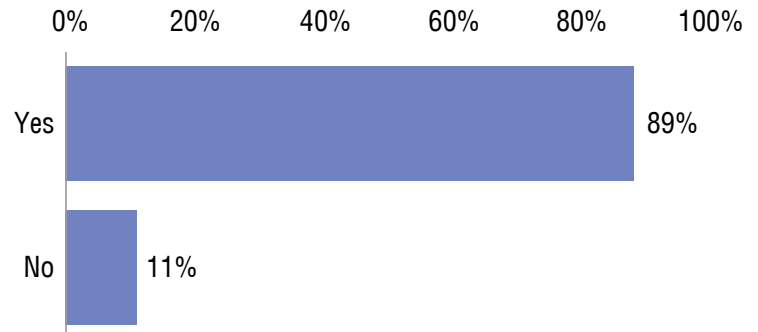

Figure 2. Do you think that the obtained rights to write the prescriptions increase the prestige of the nursing profession?

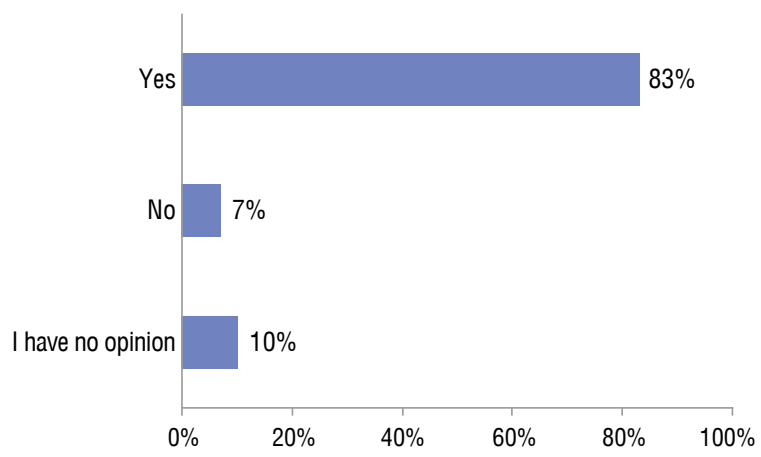

Figure 3. Do you think that the right to prescribe by nurses and midwives contributes to improving the quality of medical services?

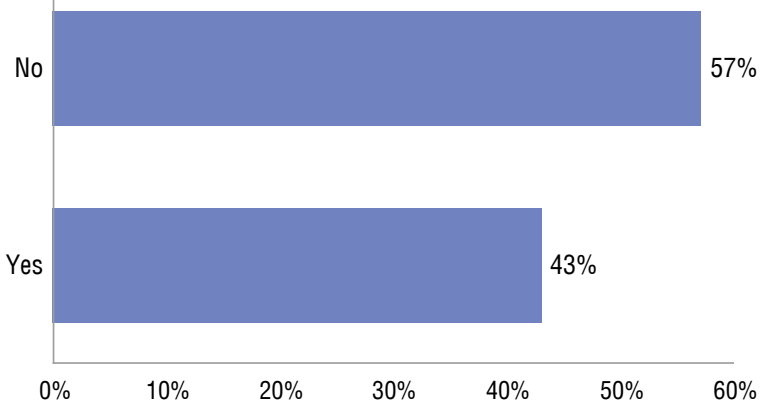

Figure 4. Is the list of drugs that you can prescribe sufficient?

\section{Discussion}

In this questionnaire study nurses opinions regarding the possibility of prescribing drugs and medical devices were explored. Most surveyed palliative care nurses believe that the obtained right to prescribe drugs and write prescriptions increase the prestige of the nursing profession and contribute to the improvement of the quality of medical services. The results are similar to Stodolak [2] and Bejster [9]. Experts 


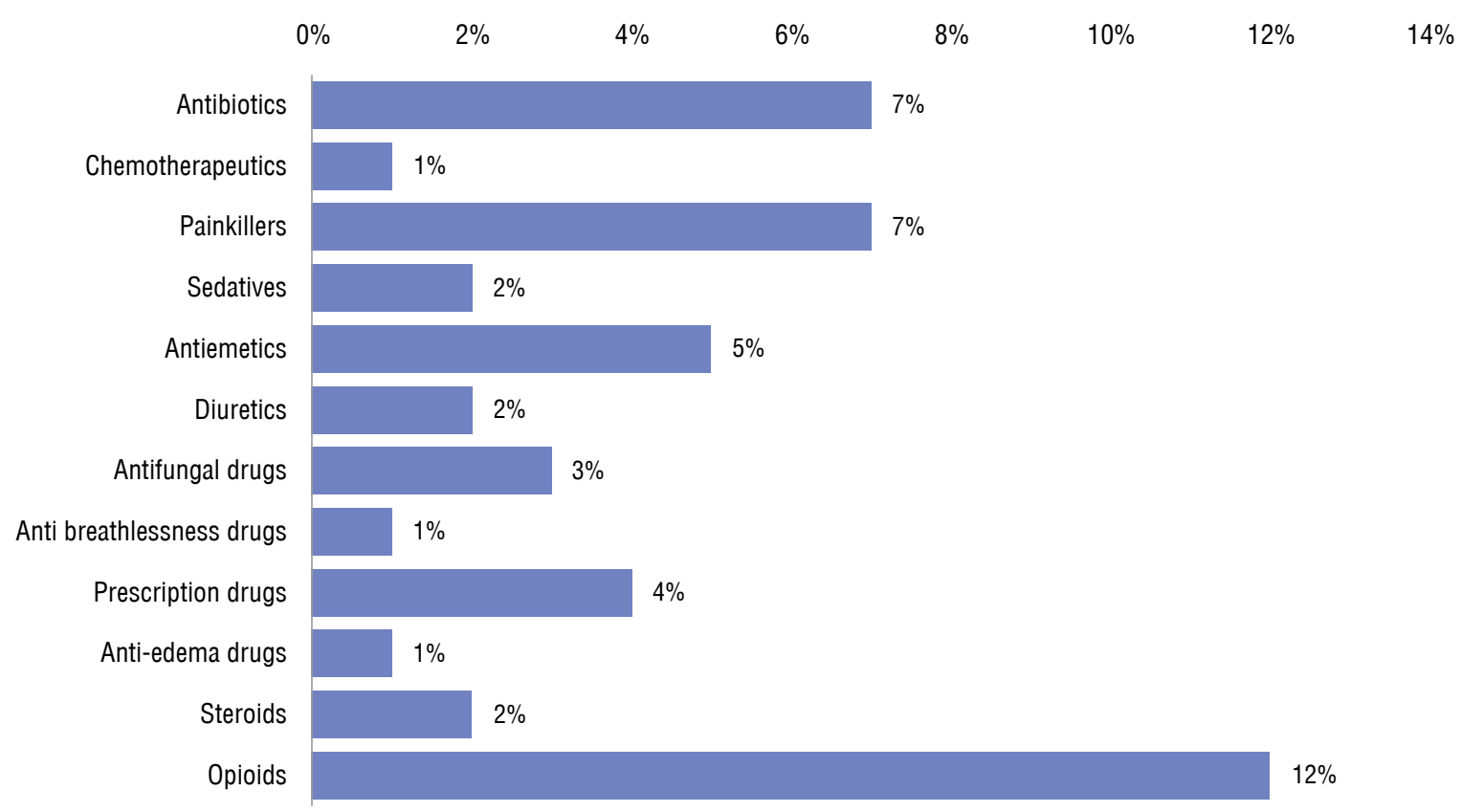

Figure 5. What medications, in your opinion, would be helpful in self-ordination by nurses in palliative care (multiple answers possible)

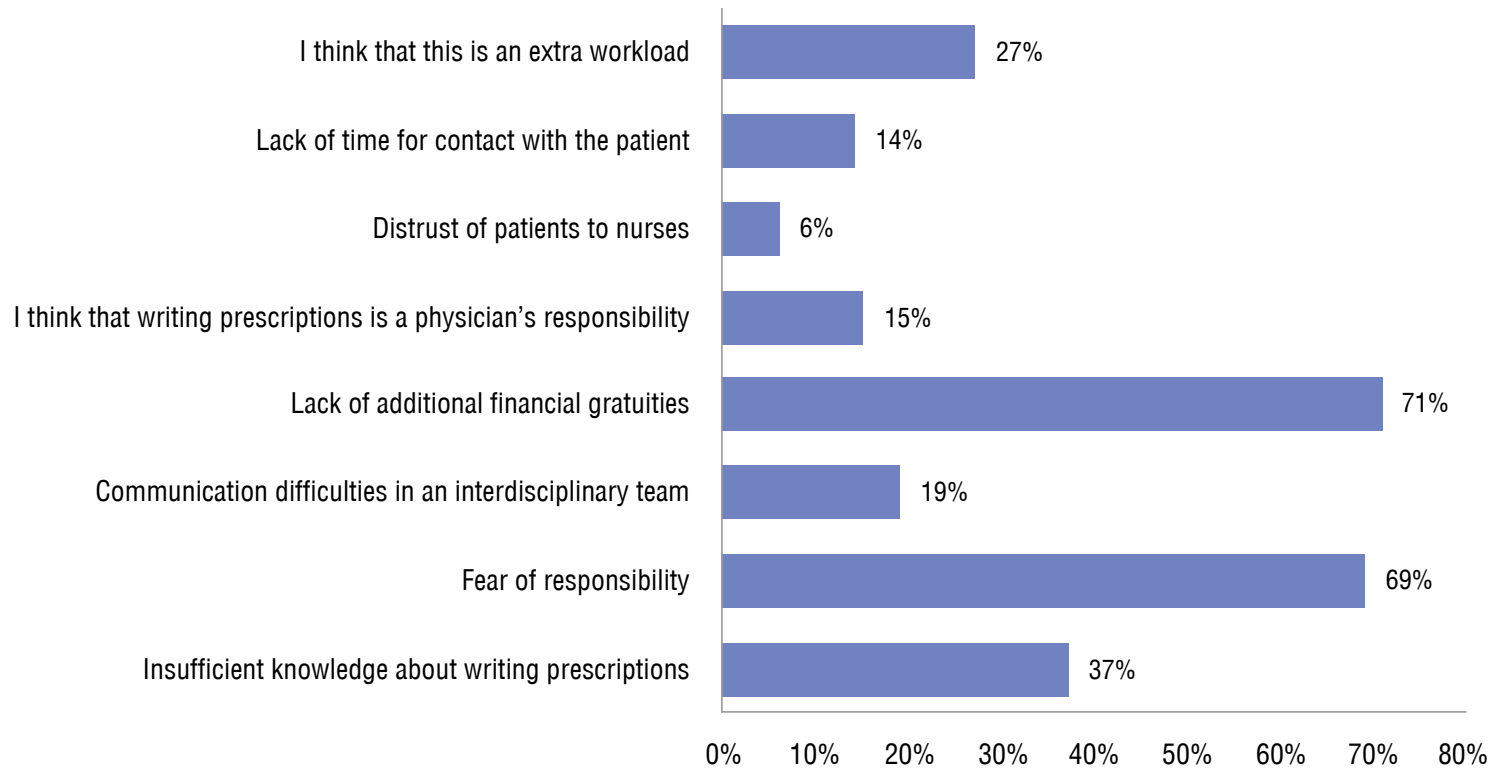

Figure 6. Barriers to issue the prescriptions by nurses (multiple answers possible)

from Sweden, Australia, the USA, England, Ireland, South Africa, New Zealand confirm the benefits of prescribing drugs by nurses and midwives [10-13]. Professionals who in their practice write prescriptions claim that it increases the prestige of the nursing profession. The higher the education, the more often confirmation is given regarding the prestige of the nursing profession due to the possibility of issuing prescriptions. The experience of other countries shows a great need to increase the competencies of nurses with the possibility of dispensing drugs and writing prescriptions and show many benefits from extending nursing qualifications. The number of countries where nurses can prescribe drugs is growing significantly, and Poland is another of them, where the competencies of nurses have been extended [10, 14-19]. The introduction of such solutions is aimed at improving the availability of medical services, reducing queues to doctors, ensuring appropriate standards of care, as well as increasing the professional prestige of nurses. 
Table 2. The level of education and completion of a specialist course: Prescribing drugs and writing prescriptions for nurses and midwives

\begin{tabular}{lllll} 
& $\begin{array}{l}\text { During a course } \\
\text { During studies }(n=9)\end{array}$ & $\begin{array}{l}\text { During specialist course } \\
(\mathrm{n}=1)\end{array}$ & $\begin{array}{l}\text { No }(\mathrm{n}=18) \\
\text { Yes }(\mathrm{n}=72)\end{array}$ \\
\hline Secondary education & $0(0 \%)$ & $0(0 \%)$ & $6(33.3 \%)$ & $7(9.7 \%)$ \\
\hline During master's degree studies & $8(88.9 \%)$ & $0(0 \%)$ & $0(0 \%)$ & $16(22.2 \%)$ \\
\hline Master's degree & $0(0 \%)$ & $1(100 \%)$ & $8(44.4 \%)$ & $42(58.3 \%)$ \\
\hline Bachelor's degree & $1(11.1 \%)$ & $0(0 \%)$ & $4(22.2 \%)$ & $7(9.7 \%)$ \\
\hline Fisher exact test & $\mathrm{p}<0.0001$ & & & \\
\hline
\end{tabular}

Table 3. Have you ever encountered a pharmacist's refusal to fulfil a prescription issued by a nurse?

\begin{tabular}{ll} 
Answers & $\begin{array}{l}n=93 \\
\text { Number of respondents } \\
(\%)\end{array}$ \\
Yes & $35(37.63 \%)$ \\
\hline No & $58(62.37 \%)$ \\
\hline
\end{tabular}

Table 4. Reasons for not fulfilling a prescription issued by a nurse - only those responding "yes" in Table 3, multiple answers possible

\begin{tabular}{ll} 
Answers & $\begin{array}{l}n=35 \\
\text { Number of } \\
\text { respondents } \\
(\%)\end{array}$ \\
\hline $\begin{array}{l}\text { Formally incorrectly issued prescription } \\
\text { by the nurse }\end{array}$ & $1(3 \%)$ \\
\hline $\begin{array}{l}\text { Pharmacist insufficient knowledge of } \\
\text { nurses' right to issue prescriptions }\end{array}$ & $24(69 \%)$ \\
\hline $\begin{array}{l}\text { The prescription was filled out of the } \\
\text { refund (with a } 100 \% \text { fee) }\end{array}$ & $8(23 \%)$ \\
\hline $\begin{array}{l}\text { The pharmacist refused to dispense } \\
\text { the drug }\end{array}$ & $9(26 \%)$ \\
\hline $\begin{array}{l}\text { Pharmacist lack of knowledge about } \\
\text { the list of drugs that nurses and mid- } \\
\text { wives can prescribe }\end{array}$ & $24(69 \%)$ \\
\hline
\end{tabular}

It seems that the number of palliative care nurses who undertake the prescription process is increasing. According to our research, more than half (55\%) of hospice nurses use this entitlement. Writing prescriptions by nurses and midwives is a new tool, an evolving practice, an ongoing process. These competencies are used as a great opportunity that helps to strengthen the prestige of the nursing profession and improve the quality of medical services $[8,20]$. The number of countries extending nursing competencies to include ordinating and prescribing drugs is increasing [11-13, 21].
The possibility of nurses' prescriptions at the present time of the COVID-19 pandemic is gaining particular importance. The implementation of prescriptions, e-prescriptions and other e-health services is a challenge for contemporary Polish nursing. The positive sides of e-health were noticed and appreciated not only by healthcare professionals but also by patients and all citizens in Poland, since on 11th March 2020, the World Health Organization (WHO) declared the COVID-19 pandemic. The circumstances forced a significant limitation of interpersonal contacts, and the recommendations of the then Minister of Health and the Chief Sanitary Inspector referred to the use of e-advice in health facilities. Act of March 31, 2020, amending certain acts in the field of the health care system related to the prevention, counteraction and combating of COVID-19 (Journal of Laws 2020, item 567) and art. 11, point 15 sanctions the possibility of using advice by phone in nursing practice [22].

The main barriers to writing prescriptions indicated by nurses are the fear of responsibility (69\%) and the lack of additional financial gratification (71\%). This is confirmed by a study conducted in 2017 and the pilot survey in 2019 [unpublished data]. In Poland, nurses still earn little, and this is one of the barriers to expanding their professional competencies and training. This is reflected in the results as only $29 \%$ of surveyed nurses received additional financial rewards for writing prescriptions. In another study 60 out of 65 respondents claim that nurses should receive appropriate remuneration for additional work [2].

Among the surveyed palliative care nurses, $72 \%$ confirmed that they had completed the prescribing drugs and writing prescriptions course, and $10 \%$ were during such course. It is also an upward trend because in 2017 only $31 \%$ of respondents completed such courses (unpublished data). Significantly more nurses with higher education completed courses on prescribing drugs and writing prescriptions. Those who completed such a course are mostly nurses with higher education of the second degree. Palliative care nur- 
ses more and more often and more willingly use the acquired competencies in their professional practice.

A total of $57 \%$ of surveyed palliative care nurses confirm that the list of drugs that they can prescribe themselves is insufficient. Similar results were obtained in a research study in 2017 - over $62 \%$ considered the list of drugs to be too narrow. Opioids were the most frequently requested (unpublished data).

The awareness of nurses, physicians and society in terms of acquired competencies, increased autonomy and professional prestige should be raised, as well as nurses should be supported and motivated in carrying out innovative tasks. Nurses are currently appreciated as important members of the interdisciplinary team. It is a professional group that is ready to perform specialist functions due to its knowledge and experience in managing patient care. Expanding competencies should benefit both patients and healthcare providers. At the same time, the growing responsibility and scope of duties of nurses should be followed by higher salaries for this professional group. When performing a free, independent profession, a nurse may choose a workplace where the scope of tasks and duties is adequate to the level of remuneration. Integrated care offers opportunities for teamwork in the healthcare system. Among nurses, strengthening their professional status and legalizing their work are of great importance, which may also contribute to relieving the work of physicians $[2,8,23,24]$.

In recent five years, intensive work has been underway in Poland related to the digitization of health care, an extension of nursing competencies, as well as professional and economic independence [25-27]. New opportunities for the nursing profession and the entire health care system are also introduced using information technology and telecommunications. The professional roles of nurses are broadening, and they perform more and more often their work by conducting individual and group nursing practice. Contractual agreements enable to achieve complete independence in professional practice, they increase the chances on the health care market and create opportunities for higher salaries and raising the professional rank of nurses [3]. These changes respond to the health expectations of patients and their families, as well as of the entire health care system. Consultations and monitoring of the patient's condition at a distance, visits with the use of videophone, e-prescriptions, e-leaves, e-referrals or advice by phone are the future of the contemporary practice of all members of the interdisciplinary palliative care team [7, 28-30]. Professional independence is important for nurses [31, 33]. New perspectives in nursing practice contribute to an improvement of the quality of medical services provided by reducing the waiting time for drugs, especially in rural areas, several dozen kilometres away from urban agglomerations. Similarly, it results in faster relief of symptoms related to the progressive, incurable disease and improvement of the quality of life of patients and their families in a holistic dimension.

Limitations of the study include a modest number of participants that may be not representative of the nurses working in all types of palliative care in Poland, a limited number of questions and administration of the questionnaire only once.

\section{Conclusions}

1. Most of the surveyed nurses expressed views that the obtained possibility to prescribe drugs increases the prestige of the nursing profession and may contribute to the improvement of the quality of medical services.

2. Lack of additional financial gratification and fear of responsibility are the main barriers to issuing prescriptions by nurses.

3. Palliative care nurses with higher education level more often complete courses to improve their qualifications in the field of prescribing drugs and writing prescriptions.

4. The majority of surveyed suggest expanding the list of drugs that they could prescribe.

\section{Declaration of conflict of interests}

The authors declare that there is no conflict of interest.

Funding

None declared.

\section{References}

1. Ustawa o zawodach pielęgniarki i położnej z dnia 15 lipca 2011 r. (tj. Dz. U.2020, poz.562 z późn. zm.).

2. Stodolak A. Opinie studentów na temat wypisywania recept przez pielęgniarki. Acta Scholae Superioris Medicinae Legnicensis. 2016; 1(17): 41-57.

3. Labuda D, Chorążewicz M, Labuda D, et al. Kontrakt jako alternatywna forma zatrudnienia pielęgniarek $\mathrm{w}$ szpitalu. Probl Piel. 2013; 21(3): 388-396.

4. Rozporządzenie Ministra Zdrowia w sprawie wykazu substancji czynnych zawartych w lekach, środków spożywczych specjalnego przeznaczenia żywieniowego i wyrobów medycznych ordynowanych przez pielęgniarki i położne oraz wykazu badań diagnostycznych, na które mają prawo wystawiać skierowania pielęgniarki i położne $z$ dnia 18 stycznia 2018 r. (Dz. U. 2018, poz.299).

5. Bartosiewicz A, Binkowska-Bury M, Januszewicz $P$, et al. Możliwość przepisywania recept przez pielęgniarki i położne - stan prawny w Polsce i ogólny przegląd sytuacji na świecie. Przegląd Medyczny Uniwersytetu Rzeszowskiego i Narodowego Instytutu Leków w Warszawie. 2015; 13(3): 290-305, doi: 10.15584/przmed.2015.3.9. 
6. Rozporządzenie Ministra Zdrowia z dnia 13 kwietnia $2018 \mathrm{r}$. w sprawie recept (Dz. U. 2018, poz.745 z późn. zm.).

7. Binkowska-Bury $M$, Nagórska $M$, Januszewicz $P$, et al. Współczesna wizja pielęgniarstwa w systemie e-zdrowia. Problemy Pielęgniarstwa. 2010; 18(3): 342-347.

8. Fuglewicz A. Nowe uprawnienia pielęgniarek i położnych z perspektywy lekarza. Acta Scholae Superioris Medicinae Legnicensis. 2016; 1(17): 58-67.

9. Bejster I. Opinie na temat ordynowania leków/wypisywania recept w środowisku pielęgniarek. Acta Scholae Superioris Medicinae Legnicensis. 2016; 1(17): 26-40.

10. Bartosiewicz A, Binkowska-Bury M, Marć M, et al. Gotowość pielęgniarek do ordynowania leków i wypisywania recept. Problemy Pielęgniarstwa. 2016; 24(2): 91-97, doi: 10.5603/pp.2016.0015.

11. Fong J, Buckley T, Cashin A, et al. Nurse practitioner prescribing in Australia: A comprehensive literature review. Aust Crit Care. 2017; 30(5): 252-259, doi: 10.1016/j. aucc.2016.11.003, indexed in Pubmed: 27913033.

12. Wainwright A, Klein T, Daly C, et al. Competency Development to Support Safe Nurse Practitioner Prescribing of Controlled Drugs and Substances in British Columbia. Policy Polit Nurs Pract. 2016; 17(3): 125-135, doi: 10.1177/1527154416665099, indexed in Pubmed: 27572237.

13. Gielen SC, Dekker J, Francke AL, et al. The effects of nurse prescribing: a systematic review. Int J Nurs Stud. 2014; 51(7): 1048-1061, doi: 10.1016/j.ijnurstu.2013.12.003, indexed in Pubmed: 24398118.

14. Ziegler L, Bennett MI, Mulvey M, et al. Characterising the growth in palliative care prescribing 2011-2015: Analysis of national medical and non-medical activity. Palliat Med. 2018; 32(4): 767-774, doi: 10.1177/0269216317739805, indexed in Pubmed: 29130384.

15. Ryan-Woolley BM, McHugh GA, Luker KA, et al. Prescribing by specialist nurses in cancer and palliative care: results of a national survey. Palliat Med. 2007; 21(4): 273-277, doi: 10.1177/0269216307079047, indexed in Pubmed: 17656402.

16. Ziegler L, Bennett M, Blenkinsopp A, et al. Non-medical prescribing in palliative care: a regional survey. Palliat Med. 2015; 29(2): 177-181, doi: 10.1177/0269216314557346, indexed in Pubmed: 25501312.

17. Quinn B, Lawrie I. Developing nurse independent prescribing in a specialist palliative care setting. Int J Palliat Nurs. 2010; 16(8): 401-405, doi: 10.12968/ijpn.2010.16.8.401, indexed in Pubmed: 20852516.

18. O'Rourke T, Kirk J, Duff E, et al. A survey of nurse practitioner controlled drugs and substances prescribing in three Ca- nadian provinces. J Clin Nurs. 2019; 28(23-24): 4342-4356, doi: 10.1111/jocn.15008, indexed in Pubmed: 31318988.

19. Kiliańska D, Gaworska-Krzemińska A (ed.). Wdrażanie uprawnień do przepisywania leków przez pielęgniarki. Uaktualniony przegląd praktyki przepisywania leków przez pielęgniarki na świecie. Polskie Towarzystwo Pielęgniarskie 2011. http:// www.ptp.na1.pl/pliki/nurse_prescribing/Nurse $\% 20$ prescribing_PL\%2002.01.2012.pdf (12.01.2020).

20. Binkowska-Bury M, Bartosiewicz A, Marć M, et al. Nowe ustawodawstwo dotyczące możliwości samodzielnego ordynowania leków i wystawiania recept przez pielęgniarki w Polsce: poglądy lekarzy podstawowej opieki zdrowotnej. Medycyna Rodzinna. 2016; 19(2): 47-54.

21. Binkowska-Bury $M$, Bartosiewicz $A$, Marć $M$, et al. Opinia pacjentów Podstawowej Opieki Zdrowotnej na temat ordynowania wybranych leków i wystawiania recept przez pielęgniarki. Hygeia Public Health. 2016; 51(2): 161-170.

22. Ustawa $z$ dnia 31 marca 2020 r. o zmianie niektórych ustaw w zakresie systemu ochrony zdrowia związanych z zapobieganiem, przeciwdziałaniem i zwalczaniem COVID-19 (tj. Dz.U.2020, poz. 567 z późń. zm.).

23. Dominiak I, Grabowska H, Gaworska-Krzemińska A. Ordynowanie leków i wypisywanie recept. Przewodnik dla pielęgniarek i położnych. Edumetriq, Sopot 2017.

24. Pędzyński B, Pędzyński B. Siostro ja tylko po receptę. Menedżer Zdrowia. 2016(4-5): 74-75.

25. Ustawa $z$ dnia 28 kwietnia $2011 \mathrm{r}$. o systemie informacji w ochronie zdrowia (tj. Dz.U.2019, poz.408 z póź. zm.).

26. Ustawa $z$ dnia 1 marca 2018 r. o zmianie niektórych ustaw w związku z wprowadzeniem e-recepty (tj. Dz.U. 2018, poz. 697).

27. Ustawa z dnia 19 lipca 2019 r. o zmianie niektórych ustaw w związku z wdrażaniem rozwiązań w obszarze e-zdrowia (tj. Dz.U.2019, poz.1590).

28. Drela K. Pacjenci, a e-zdrowie. Zeszyty Naukowe Uniwersytetu Szczecińskiego. Studia Informatica. 2010; 25: 115-126.

29. Antczak A. Zastosowanie telepielęgniarstwa w praktyce pielęgniarki neurologicznej. Piel Neurol Neurochir. 2013; 3: 130-134.

30. Kiliańska D, Grabowska H, Gaworska-Krzemińska A. E-zdrowie wprowadzenie do informatyki w pielęgniarstwie. PZWL, Warszawa 2018.

31. De Walden-Gałuszko K, Kaptacz A. Pielęgniarstwo opieki paliatywnej. PZWL, Warszawa 2017.

32. Boruń T. Rola pielęgniarki w opiece paliatywnej i hospicyjnej - opis przypadku Adama. Piel Zdr Publ. 2011; 1(3): 289-295.

33. Łuczak J, Kotlińska-Lemieszek A. Opieka paliatywna/hospicyjna/medycyna paliatywna. Now Lek. 2011; 80(1): 3-15.
Appendix. A questionnaire used in the study

\section{Questionnaire}

Demographics

Age:

20-30 years old

31-40 years old

41-50 years old

Over 51 years old

\section{Education:}

$\square$ Secondary (medical high school, medical vocational school)

$\square$ Higher first degree - Bachelor of Nursing

$\square$ Higher second degree - Master of Nursing

$\square$ During second degree - Master of Nursing
Higher education in a different field:

Master's degree in

Completed postgraduate education:

Specialization in the field.

Qualification course in the field

A different type of course

Work experience in palliative care:

$\square<5$ years

6-10 years

11-15 years 


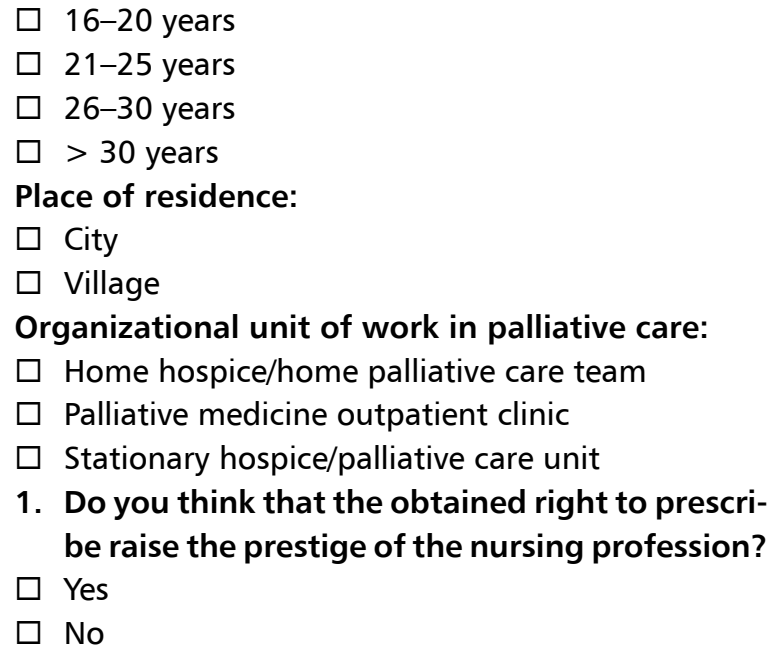

2. Have you completed the specialist course: Prescribing drugs and writing prescriptions for nurses and midwives?

Yes

No

During the course

During master's degree studies in nursing

3. Do you prescribe in your nursing practice? (If you have such rights)

$\square$ Yes

$\square$ No

4. Do you think that the right to prescribe by nurses and midwives contributes to the improvement of the quality of medical services?

$\square$ Yes

$\square$ No

$\square$ I have no opinion

5. Do you think that the possibility of prescribing by nurses and midwives increases patients' trust in these professions?

$\square$ Yes

$\square$ No

$\square$ I have no opinion

6. Is the possibility of prescribing and continuing treatment useful in the work of a palliative care nurse?

Yes

$\square$ No

7. Do you also participate in workshops, conferences, trainings related to the subject of prescribing and update your knowledge on this subject regularly?

$\square$ Yes

No

8. Do you use applications that facilitate and improve prescribing? (e.g., dr Widget, Pharmindex, Empendium)

$\square$ Yes

$\square$ No
I am not familiar with such applications

9. In what form do you issue prescriptions?

Electronic/e-prescription

Paper/ready-made prescription forms

Printout from a computer

10.In your professional practice, do you prescribe medical devices and write orders for them?

Yes

No

11. For whom do you issue prescriptions? (You can choose several answers)

$\square$ Pro auctore/for myself

Pro familia/for family

Proteges

On the recommendation of a doctor

I do not issue prescriptions

12. Have you obtained additional financial rewards for writing prescriptions?

Yes

No

13. Have you ever encountered a pharmacist's refusal to fulfil a prescription issued by a nurse?

Yes

$\square$ No

If yes, what was the reason for the refusal (multiple answers possible)

$\square$ Formallyincorrectly issued prescription by thenurse

$\square$ Pharmacist insufficient knowledge of nurses' right to issue prescriptions

$\square$ The prescription was filled out of the refund (with a $100 \%$ fee)

$\square$ The pharmacist refused to dispense the drug

$\square$ Pharmacist lack of knowledge about the list of drugs that nurses and midwives can prescribe

14. Is the list of drugs that you can prescribe yourself sufficient?

Yes

No

If no, what drugs do you think would be helpful for self-ordination by nurses in palliative care (please specify)

15. What are the barriers to prescribe by nurses? (multiple answers possible)

$\square$ Insufficient knowledge about writing prescriptions Fear of responsibility

$\square$ Communication difficulties in an interdisciplinary team

$\square$ Lack of additional financial gratuities

$\square$ I think that writing prescriptions is a physician's responsibility

$\square$ Distrust of patients to nurses

$\square$ Lack of time for contact with the patient

I think that this is an extra workload 


\section{Wypisywanie recept przez pielęgniarki i pielęgniarzy opieki paliatywnej} w Polsce

Artykuł jest tłumaczeniem pracy: Kosińska B., Zalas A., Writing prescriptions by palliative care nurses in Poland. Palliat. Med. Pract. 2021, tom 15, nr 2: 127-134.

Należy cytować wersję pierwotną.

\section{Streszczenie}

Wstęp: Pozwolenie na przepisywanie leków oraz wyrobów medycznych przez pielęgniarki, pielęgniarzy i położne wprowadzono w Polsce na początku 2014 roku. Następnie Ministerstwo Zdrowia przedstawiło projekt nowelizacji ustawy o zawodzie pielęgniarki/pielęgniarza i położnej. Celem badania było poznanie opinii pielęgniarek i pielęgniarzy na temat możliwości przepisywania leków oraz wyrobów medycznych. Materiał i metody: Badanie przeprowadzono w okresie od stycznia do lutego 2020 roku wśród 100 pielęgniarek z całej Polski świadczących opiekę paliatywną. Wykorzystano do tego celu własny kwestionariusz składający się z 23 pytań.

Wyniki: Wszyscy uczestnicy odpowiedzieli na pytania zawarte w kwestionariuszu (wskaźnik odpowiedzi $=100 \%$ ). Ponad połowa respondentów $(55 \%)$ wypisuje recepty w ramach opieki paliatywnej. Zdecydowana większość respondentów (89\%) potwierdziła, że otrzymanie uprawnień do wypisywania recept podnosi prestiż zawodu, a $83 \%$ respondentów sądziło, że przyczynia się to do podniesienia jakości usług medycznych. Łącznie $57 \%$ uczestników stwierdziło, że należy rozszerzyć listę leków, które mogą być wypisywane przez pielęgniarki i pielęgniarzy świadczących opiekę paliatywną.

Wnioski: Zdecydowana większość ankietowanych pielęgniarek i pielęgniarzy stwierdziła, że możliwość przepisywania leków podnosi prestiż ich zawodu oraz przyczynia się do poprawy jakości usług medycznych świadczonych przez pielęgniarki i pielęgniarzy.

Palliat Med Pract 2021; 15, 2: 135-143

Słowa kluczowe: pielęgniarka, opieka paliatywna, recepty, leki, wyroby medyczne

\section{Adres do korespondencji:}

Bożena Kosińska

Wyższa Szkoła Zarządzania w Częstochowie

ul. Krychnowicka 1, 26-600 Radom, Polska

tel.: 509037 118, e-mail: bozko@vp.pl

Artykuł jest dostępny bezpłatnie na podstawie licencji Creative Common Attribution-Non-Commercial-No Derivatives 4.0 International (CC BY-NC-ND 4.0) umożliwiającej jego pobranie oraz udostępnianie pod warunkiem wskazania autorstwa i wydawcy. Niedopuszczalne jest wprowadzanie jakichkolwiek zmian lub wykorzystanie komercyjne bez zgody wydawcy. 


\section{Wstęp}

Pozwolenie na przepisywanie leków oraz wyrobów medycznych przez pielęgniarki, pielęgniarzy i położne wprowadzono w Polsce na początku 2014 roku. Następnie Ministerstwo Zdrowia przedstawiło projekt nowelizacji ustawy o zawodzie pielęgniarki/pielęgniarza i położnej. Z dniem 1 stycznia 2016 roku polskie pielęgniarki i położne uzyskały uprawnienia do przepisywania leków i środków spożywczych specjalnego przeznaczenia, a także szerokiej gamy wyrobów medycznych. Stanowi to postęp w zakresie praktyki pielęgniarskiej w naszym kraju [1-3].

W zależności od poziomu wykształcenia, pielęgniarki i położne mogą przepisywać leki zawierające określone substancje czynne oraz wystawiać zlecenia na wyroby medyczne. Pielęgniarki i położne z tytułem magistra oraz specjaliści w dziedzinie pielęgniarstwa posiadają największe uprawnienia, ponieważ mogą samodzielnie przepisywać leki i produkty lecznicze określone w rozporządzeniu Ministra Zdrowia z dnia 18 stycznia 2018 roku (Dz. U. z 2018 r. poz. 299), a także wystawiać skierowania na badania diagnostyczne. Pielęgniarki i położne z tytułem licencjata mogą wystawiać recepty na leki stosowane w ramach kontynuacji zaplanowanego przez lekarza leczenia. W celu uzyskania nowych uprawnień obie grupy muszą ukończyć specjalistyczny kurs w tym zakresie. Od roku akademickiego 2017/2018 studenci zdobywają wiedzę z tego zakresu w trakcie kształcenia w szkołach pielęgniarskich i położniczych pierwszego i drugiego stopnia oraz na szkoleniach specjalizacyjnych. Osoby te nie muszą posiadać dodatkowego wykształcenia, aby móc wypisywać recepty [1,4-6].

Pielęgniarki mogą obecnie przepisywać pacjentom takie leki, jak: leki przeciwwymiotne — ondansetron, aprepitant, tietylperazyna; leki przeciwgrzybicze miejscowe (nystatyna - postacie do stosowania na skórę i błony śluzowe); metronidazol - w postaci do stosowania na skórę i błony śluzowe; ginekologiczne dopochwowe leki przeciwgrzybicze (np. nystatyna, natamycyna, klotrymazol), metronidazol; antybiotyki: amoksycylina, doksycyklina, fenoksymetylopenicylina; bakteriostatyki: trimetoprim; środki znieczulające miejscowo: lidokaina; leki przeciwbólowe: tramadol i tramadol z paracetamolem - w postaci doustnej i doodbytniczej; leki przeciwlękowe: hydroksyzyna [4].

Czynności wykonywane codziennie w pracy pielęgniarek paliatywnych odzwierciedlają nowe rozwiązania w zakresie wypisywania recept. Ważne jest, aby prowadzenie nowych uprawnień było postrzegane jako ogromna szansa na podniesienie prestiżu zawodu i poprawę jakości świadczonych usług medycznych, a nie jak dodatkowe obciążenie lub czynność, której wykonywanie należy wyłącznie do lekarza [7, 8]. Pielęgniarki świadczące opiekę hospicyjną są partnerami, a często także liderami zespołu medycznego. Są w codziennym kontakcie z chorymi i umierającymi, a gdy stan ogólny pacjenta szybko się zmienia, często same świadczą opiekę. Celem badania było poznanie opinii pielęgniarek i pielęgniarzy na temat możliwości przepisywania leków oraz wyrobów medycznych.

\section{Materiały i metody}

Badanie przeprowadzono w dwóch etapach. Pierwszym było badanie pilotażowe, w którym w maju 2019 roku wzięło udział 15 pielęgniarek. Drugi etap, w okresie od stycznia do lutego 2020 roku, objął grupę 100 pielęgniarek związanych z opieką paliatywną pochodzących z całej Polski. Badanie miało charakter anonimowy, a kwestionariusz zawierał dane demograficzne oraz 15 pytań dotyczących przedmiotu badania (patrz Załącznik). Na potrzeby niniejszego artykułu wybrano następujące pytania: 1-4 oraz 13-15. Wypełnienie kwestionariusza było równoznaczne z wyrażeniem zgody na udział w badaniu. Badanie przeprowadzono z użyciem formularzy internetowych (60 kwestionariuszy) oraz formularzy drukowanych (40 kwestionariuszy). Ponieważ badanie nie miało charakteru eksperymentu badawczego, nie była wymagana zgoda komisji ds. etyki.

Analizę statystyczną przeprowadzono przy użyciu pakietu statystycznego PQStat, wersja 1.8.0.324. Zależności między odpowiedziami analizowano za pomocą dokładnego testu Fishera. Prawdopodobieństwo testu na poziomie $p<0,05$ uznano za istotne.

\section{Wyniki}

Wszyscy uczestnicy odpowiedzieli na pytania zawarte w kwestionariuszu (wskaźnik odpowiedzi $100 \%$ ). Większość badanej populacji stanowiły pielęgniarki powyżej 41. roku życia (75\%), natomiast najmniej liczną grupą były pielęgniarki w wieku 20-30 lat (7\%). Wykształcenie wyższe (magisterskie) zadeklarowało $51 \%$ badanych, a $24 \%$ było w trakcie studiów magisterskich z zakresu pielęgniarstwa. Kolejne $12 \%$ posiadało wykształcenie wyższe na poziomie licencjata. Tylko $13 \%$ badanych miało wykształcenie średnie. Zdecydowana większość badanych, czyli 84\%, ukończyła specjalizację, a 49\% ukończyło kursy kwalifikacyjne z zakresu różnych dziedzin pielęgniarstwa. Prawie jedna czwarta badanych pracowała w opiece paliatywnej przez okres 6-10 lat; nieco mniej (20\%) badanych pracowało w opiece paliatywnej przez okres 21-25 lat. Doświadczenie zawodowe w opiece palia- 
Tabela 1. Charakterystyka społeczno-demograficzna badanej grupy

\begin{tabular}{|c|c|c|}
\hline & $\mathbf{N}$ & $\%$ \\
\hline \multicolumn{3}{|l|}{ Wiek } \\
\hline 20-30 lat & 7 & $7 \%$ \\
\hline $31-40$ lat & 18 & $18 \%$ \\
\hline $41-50$ lat & 46 & $46 \%$ \\
\hline Więcej niż 51 lat & 29 & $29 \%$ \\
\hline \multicolumn{3}{|l|}{ Wykształcenie } \\
\hline $\begin{array}{l}\text { Średnie (liceum medyczne, medyczna } \\
\text { szkoła zawodowa) }\end{array}$ & 13 & $13 \%$ \\
\hline $\begin{array}{l}\text { Wyższe pierwszego stopnia - licencjat } \\
\text { pielęgniarstwa }\end{array}$ & 12 & $12 \%$ \\
\hline $\begin{array}{l}\text { Wyższe drugiego stopnia - magister } \\
\text { pielęgniarstwa }\end{array}$ & 51 & $51 \%$ \\
\hline $\begin{array}{l}\text { W trakcie studiów magisterskich - magi- } \\
\text { ster pielęgniarstwa }\end{array}$ & 24 & $24 \%$ \\
\hline \multicolumn{3}{|c|}{$\begin{array}{l}\text { Ukończone studia podyplomowe (można wybrać } \\
\text { więcej niż jedną odpowiedź) }\end{array}$} \\
\hline Specjalizacja & 84 & $84 \%$ \\
\hline Kurs kwalifikacyjny & 49 & $49 \%$ \\
\hline Inne kursy & 15 & $15 \%$ \\
\hline \multicolumn{3}{|c|}{ Doświadczenie zawodowe w opiece paliatywnej } \\
\hline$<5$ lat & 15 & $15 \%$ \\
\hline 6-10 lat & 23 & $23 \%$ \\
\hline $11-15$ lat & 17 & $17 \%$ \\
\hline 16-20 lat & 13 & $13 \%$ \\
\hline $21-25$ lat & 20 & $20 \%$ \\
\hline 26-30 lat & 8 & $8 \%$ \\
\hline$>30$ lat & 4 & $4 \%$ \\
\hline \multicolumn{3}{|l|}{ Miejsce zamieszkania } \\
\hline Miasto & 63 & $63 \%$ \\
\hline Wieś & 37 & $37 \%$ \\
\hline \multicolumn{3}{|c|}{$\begin{array}{l}\text { Miejsce pracy w opiece paliatywnej (można wy- } \\
\text { brać więcej niż jedną odpowiedź) }\end{array}$} \\
\hline $\begin{array}{l}\text { Hospicjum domowe/zespół domowej } \\
\text { opieki paliatywnej }\end{array}$ & 79 & $79 \%$ \\
\hline Poradnia opieki paliatywnej & 20 & $20 \%$ \\
\hline $\begin{array}{l}\text { Hospicjum stacjonarne lub oddział opieki } \\
\text { paliatywnej }\end{array}$ & 20 & $20 \%$ \\
\hline
\end{tabular}

tywnej wynoszące więcej niż 26 lat zadeklarowało najmniej badanych (12\%) (tab. 1).

Ponad połowa (55\%) wypisuje recepty w ramach opieki paliatywnej (ryc. 1). Większość badanych potwierdziła, że uzyskane uprawnienia do przepisywania leków i wystawiania recept podnoszą prestiż zawodu (ryc. 2). Łącznie $83 \%$ badanych uważa, że prawo to przyczynia się do poprawy jakości usług medycznych

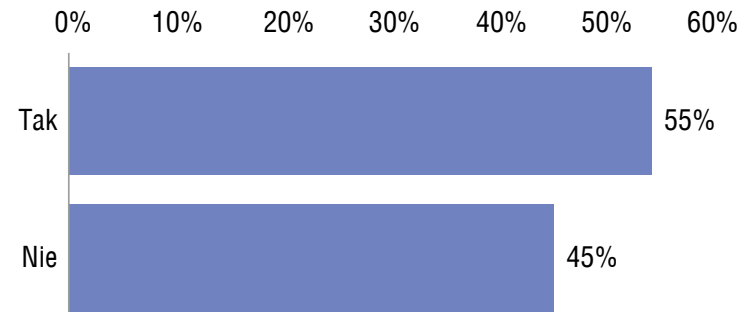

Rycina 1. Czy w ramach swojej praktyki pielęgniarskiej wypisuje Pan/Pani recepty?

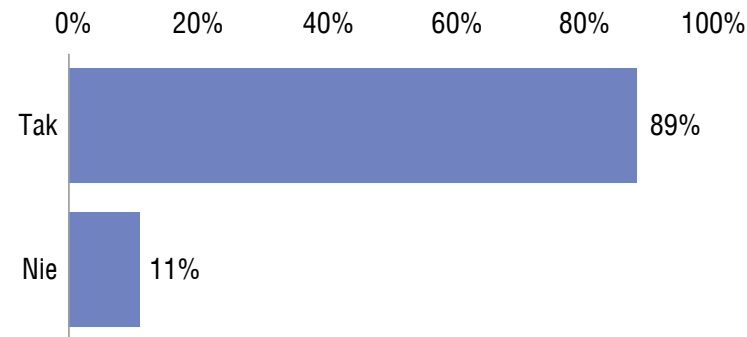

Rycina 2. Czy Pana/Pani zdaniem uzyskanie uprawnień do wypisywania recept podnosi prestiż zawodu pielęgniarki?

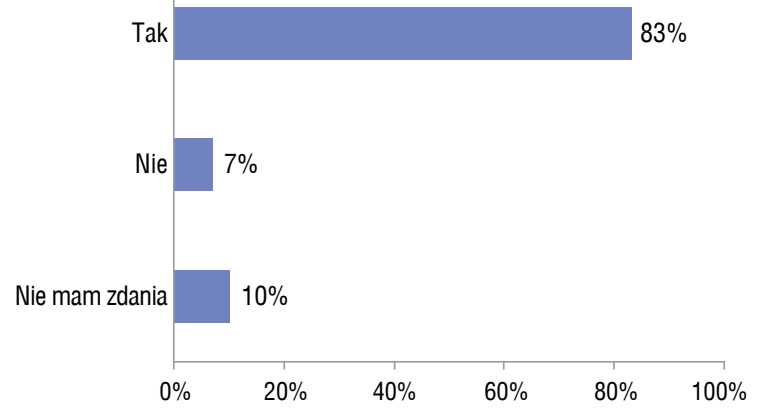

Rycina 3. Czy Pana/Pani zdaniem uprawnienia do wystawiania recept przez pielęgniarki, pielęgniarzy i położne przyczyniają się do poprawy jakości świadczeń medycznych?

(ryc. 3). Łącznie 57\% badanych stwierdziło, że należy rozszerzyć listę leków, które mogą być wypisywane przez pielęgniarki świadczące opiekę paliatywną (ryc. 4). Proponowane leki, które byłyby pomocne w codziennej pracy zawodowej pielęgniarek paliatywnych przedstawiono na rycinie 5 . Przeszkody dla wystawiania recept przez pielęgniarki przedstawiono na rycinie 6 .

Większość pielęgniarek posiadających wyższe wykształcenie ukończyła specjalistyczny kurs z zakresu wystawiania recept (tab. 2). Przy pytaniu: Czy kiedykolwiek spotkałeś/aś się z sytuacją, w której farmaceuta odmówił zrealizowania recepty wydanej przez pielęgniarkę? ponad jedna trzecia badanych stwier- 
dziła, że spotkała się z odmową farmaceuty (tab. 2). Najczęstsze przyczyny odmowy realizacji takich recept to brak dostatecznej wiedzy wśród farmaceutów na temat uprawnień pielęgniarek oraz brak wiedzy na temat listy leków, które mogą być wypisywane przez pielęgniarki i położne (tab. 4).

\section{Dyskusja}

W niniejszym badaniu ankietowym zbadano opinie pielęgniarek na temat możliwości przepisywania leków i wyrobów medycznych. Zdecydowana większość badanych pielęgniarek paliatywnych stwierdziła, że prawo do przepisywania leków i wystawiania recept zwiększa prestiż zawodu i przyczynia się do poprawy jakości usług medycznych. Wyniki te są zbliżone do wyników uzyskanych przez Stodolaka [2] i Bejstera

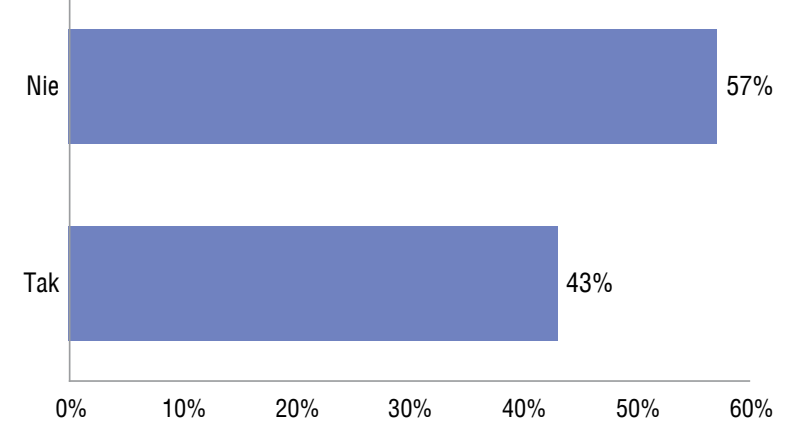

Rycina 4. Czy wykaz leków, na które ma Pan/Pani prawo wystawiać recepty, jest wystarczający?
[9]. Eksperci ze Szwecji, Australii, Stanów Zjednoczonych, Anglii, Irlandii, Afryki Południowej i Nowej Zelandii potwierdzają korzyści z przepisywania leków przez pielęgniarki i położne [10-13]. Specjaliści, którzy wystawiają recepty $w$ ramach swojej pracy twierdzą, że podnosi to prestiż zawodu. Im wyższy poziom wykształcenia, tym częściej potwierdza się prestiż zawodu pielęgniarki ze względu na możliwość wystawiania recept. Doświadczenia z innych krajów pokazują, że istnieje ogromna potrzeba rozszerzenia kompetencji pielęgniarek o możliwość wydawania leków i wystawiania recept oraz że rozszerzanie kwalifikacji pielęgniarek przynosi wiele korzyści. Liczba krajów, w których pielęgniarki mogą przepisywać leki znacząco wzrasta, a Polska jest jednym z krajów, w którym rozszerzono kwalifikacje pielęgniarek [10, 14-19]. Wprowadzenie tego typu rozwiązań ma na celu zwiększenie dostępności usług medycznych, zmniejszenie kolejek do lekarzy, zapewnienie odpowiedniego standardu opieki, a także podniesienie prestiżu zawodu pielęgniarki.

Wydaje się, że wzrasta liczba pielęgniarek paliatywnych, które zajmują się wypisywanie recept. Badania autorów pracy pokazują, że ponad połowa (55\%) pielęgniarek hospicyjnych korzysta z omawianych uprawnień. Wypisywanie recept przez pielęgniarki i położne to nowość, rozwijająca się praktyka i ciągły proces. Kompetencje te wykorzystywane są jako wyjątkowa szansa podniesienia prestiżu zawodu pielęgniarki i jakości świadczeń medycznych [8, 20]. Wzrasta liczba państw, które rozszerzają kompetencje

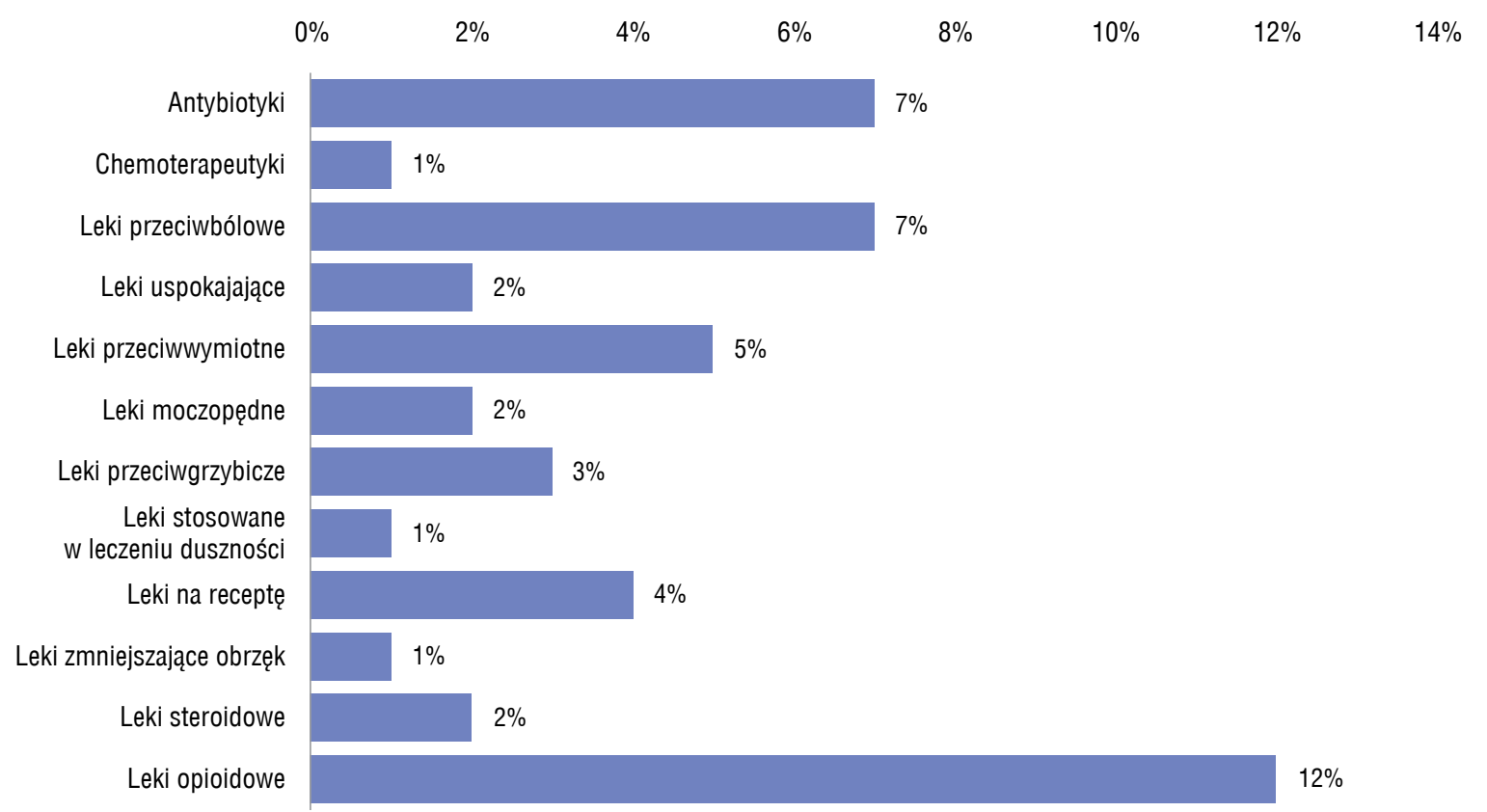

Rycina 5. Które leki Pana/Pani zdaniem powinny zostać objęte samodzielną ordynacją przez pielęgniarki/pielęgniarzy w opiece paliatywnej (można wybrać więcej niż jedną odpowiedź) 
Moim zdaniem jest to dodatkowe obciążenie w pracy

Brak czasu na kontakt z pacjentem

Nieufność pacjentów względem pielęgniarek

Uważam, że wystawianie recept jest obowiązkiem lekarza

Brak dodatkowych gratyfikacji finansowych

Trudności w komunikacji w zespole interdyscyplinarnym

Obawa przed odpowiedzialnością

Niewystarczająca wiedza na temat wypisywania recept

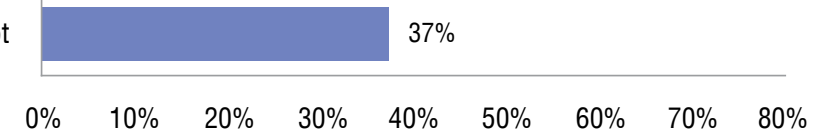

Rycina 6. Przeszkody w wystawianiu recept przez pielęgniarki i pielęgniarzy (można wybrać więcej niż jedną odpowiedź)

Tabela 2. Poziom wykształcenia i ukończenie kursu specjalistycznego „Ordynowanie leków i wypisywanie recept dla pielęgniarek i położnych"

\begin{tabular}{lllll} 
& $\begin{array}{l}\text { W trakcie kursu } \\
\text { W trakcie studiów } \\
(n=9)\end{array}$ & $\begin{array}{l}\text { W trakcie kursu } \\
\text { specjalistycznego }(n=1)\end{array}$ & $\begin{array}{l}\text { Nie }(n=18) \\
\text { Tak }(n=72)\end{array}$ \\
Wykształcenie średnie & $0(0 \%)$ & $0(0 \%)$ & $6(33,3 \%)$ & $7(9,7 \%)$ \\
\hline W trakcie studiów magisterskich & $8(88,9 \%)$ & $0(0 \%)$ & $0(0 \%)$ & $16(22,2 \%)$ \\
\hline Tytuł magistra & $0(0 \%)$ & $1(100 \%)$ & $8(44,4 \%)$ & $42(58,3 \%)$ \\
\hline Tytuł licencjata & $1(11,1 \%)$ & $0(0 \%)$ & $4(22,2 \%)$ & $7(9,7 \%)$ \\
\hline Dokładny test Fishera & $p<0,0001$ & & & \\
\hline
\end{tabular}

Tabela 3. Czy spotkał(a) się Pan/Pani w aptece z odmową realizacji recepty wystawionej przez pielęgniarkę/pielęgniarza?

\begin{tabular}{ll} 
Odpowiedzi & $\begin{array}{l}n=93 \\
\text { Liczba respondentów } \\
(\%)\end{array}$ \\
\hline Tak & $35(37,63 \%)$ \\
\hline Nie & $58(62,37 \%)$ \\
\hline
\end{tabular}

pielęgniarek o uprawnienia do przepisywania leków [11-13, 21].

Możliwość wystawiania recept przez pielęgniarki nabiera szczególnego znaczenia w obecnym czasie pandemii COVID-19. Wdrożenie wystawiania przez pielęgniarki recept, e-recept i świadczenia przez nie innych usług w zakresie e-zdrowia to wyzwanie dla współczesnego polskiego pielęgniarstwa. Pozytywne aspekty e-zdrowia zostały dostrzeżone i docenione nie tylko przez pracowników ochrony zdrowia, lecz
Tabela 4. Przyczyny odmowy realizacji recepty wystawionej przez pielęgniarkę/pielęgniarza - tylko w przypadku osób, które udzieliły odpowiedzi „Tak" w Tabeli 3, można wybrać więcej niż jedną odpowiedź

\begin{tabular}{ll}
\hline Odpowiedzi & $\begin{array}{l}\mathrm{n}=35 \\
\text { Liczba } \\
\text { responden- } \\
\text { tów (\%) }\end{array}$ \\
\hline $\begin{array}{l}\text { Braki formalne w recepcie wystawionej } \\
\text { przez pielęgniarkę/pielęgniarza }\end{array}$ & $1(3 \%)$ \\
\hline $\begin{array}{l}\text { Niewystarczająca wiedza aptekarza na } \\
\text { temat uprawnień pielęgniarek/pielę- } \\
\text { gniarzy do wystawiania recept }\end{array}$ & $24(69 \%)$ \\
\hline $\begin{array}{l}\text { Receptę wystawiono poza zakresem } \\
\text { refundacji (odpłatność 100\% ) }\end{array}$ & $8(23 \%)$ \\
\hline $\begin{array}{l}\text { Aptekarz odmówił wydania leku } \\
\text { Brak wiedzy aptekarza na temat wyka- } \\
\text { zu leków objętych zakresem upraw- } \\
\text { nień pielęgniarek/pielęgniarzy } \\
\text { i położnych do ich przepisywania }\end{array}$ & $9(26 \%)$ \\
\hline
\end{tabular}


również przez pacjentów i wszystkich Polaków po tym, jak 11 marca 2020 roku Światowa Organizacja Zdrowia (WHO, World Health Organization) ogłosiła pandemię COVID-19. Okoliczności wymusiły znaczne ograniczenie kontaktów interpersonalnych, a zalecenia ówczesnego ministra zdrowia i głównego inspektora sanitarnego wskazywały na korzystanie z e-porad w placówkach ochrony zdrowia. Ustawa z dnia 31 marca 2020 r. o zmianie niektórych ustaw w zakresie systemu ochrony zdrowia związanych z zapobieganiem, przeciwdziałaniem i zwalczaniem COVID-19 (Dz.U. z 2020 r., poz. 567) oraz art. 11, pkt 15 ustawy sankcjonuje możliwość udzielania teleporad w praktyce pielęgniarskiej [22].

Główne przeszkody w wypisywaniu recept wskazywane przez pielęgniarki to obawa przed odpowiedzialnością (69\%) oraz brak dodatkowej gratyfikacji finansowej (71\%). Potwierdza to badanie przeprowadzone w 2017 roku oraz badanie pilotażowe z 2019 roku (dane niepublikowane). Zarobki pielęgniarek w Polsce są w dalszym ciągu niskie i jest to jedną z przeszkód w podnoszeniu ich kompetencji zawodowych i ich udziale w szkoleniach. Znajduje to odzwierciedlenie w wynikach, gdyż jedynie $29 \%$ badanych pielęgniarek/pielęgniarzy otrzymywało dodatkowe gratyfikacje finansowe za wypisywanie recept. W innym badaniu 60 z 65 respondentów stwierdziło, że pielęgniarki i pielęgniarze powinni/powinny otrzymywać odpowiednie wynagrodzenie za dodatkowy nakład pracy [2].

Ukończenie kursu w zakresie przepisywania leków i wystawiania recept potwierdziło $72 \%$ spośród ankietowanych pielęgniarek opieki paliatywnej, a 10\% było $w$ trakcie takiego kursu. Jest to również tendencja wzrostowa, ponieważ w 2017 roku tylko 31\% ankietowanych miało ukończony tego rodzaju kurs (dane niepublikowane). Istotnie większa liczba pielęgniarek posiadających wykształcenie wyższe ukończyła kursy z zakresu wystawiania recept. Pielęgniarki, które ukończyły taki kurs to w większości osoby posiadające wykształcenie wyższe drugiego stopnia. Pielęgniarki opieki paliatywnej coraz częściej i chętniej wykorzystują zdobyte kompetencje w swojej praktyce zawodowej.

Łącznie 57\% ankietowanych pielęgniarek opieki paliatywnej potwierdza, że wykaz leków, które mogą samodzielnie przepisywać, jest niewystarczający. Podobne wyniki uzyskano w badaniu z 2017 roku — ponad $62 \%$ badanych stwierdziło, że wykaz leków jest niewystarczający. Najczęściej zgłaszano potrzebę uwzględnienia w nim opioidów.

Należy podnosić świadomość pielęgniarek, lekarzy i społeczeństwa w zakresie kompetencji uzyskanych przez pielęgniarki, zwiększenia ich autonomii i prestiżu zawodu, a także wspierać i motywować pielęgniarki w realizacji nowych zadań. Pielęgniarki są obecnie doceniane jako ważni członkowie zespołu interdyscyplinarnego. Z uwagi na posiadaną wiedzę i doświadczenie w zarządzaniu opieką nad pacjentem, stanowią one grupę zawodową gotową do pełnienia funkcji specjalistów. Rozszerzanie kompetencji powinno przynieść korzyści zarówno pacjentom, jak i świadczeniodawcom opieki zdrowotnej. Jednocześnie zwiększanie odpowiedzialności i zakresu obowiązków pielęgniarek powinno pociągać za sobą wyższe wynagrodzenia dla tej grupy zawodowej. Wykonując wolny, samodzielny zawód, pielęgniarka może wybrać miejsce pracy, w którym wysokość wynagrodzenia będzie adekwatna do zakresu zadań i obowiązków. Opieka zintegrowana oferuje możliwości w zakresie pracy zespołowej w systemie opieki zdrowotnej. Wśród pielęgniarek duże znaczenie ma podniesienie ich statusu zawodowego i prawne uregulowanie ich pracy, a także może przyczynić się do odciążenia lekarzy [2, 8, 23, 24].

W ciągu ostatnich pięciu lat w Polsce prowadzono intensywne prace $w$ związku z cyfryzacją ochrony zdrowia, poszerzaniem kompetencji pielęgniarek i ich usamodzielnieniem zawodowym i ekonomicznym [25-27]. Wykorzystanie technologii informacyjnych i telekomunikacyjnych również dostarcza nowych możliwości dla zawodu pielęgniarki i całego systemu ochrony zdrowia. Poszerza się również zakres ról zawodowych pielęgniarek, które coraz częściej wykonują swoją pracę $w$ ramach indywidualnej lub grupowej praktyki pielęgniarskiej. Umowy kontraktowe pozwalają na osiągnięcie pełnej niezależności w praktyce zawodowej, zwiększają szanse na rynku ochrony zdrowia i stwarzają możliwości na uzyskanie wyższych zarobków i podniesienie rangi zawodu pielęgniarki [3]. Zmiany te są odpowiedzią na oczekiwania pacjentów i ich rodzin, jak również całego systemu ochrony zdrowia. Konsultacje i monitorowanie stanu chorego na odległość, wizyty z wykorzystaniem wideotelefonu, e-recepty, e-zwolnienia, e-skierowania czy porady przez telefon to przyszłość współczesnej praktyki wszystkich członków interdyscyplinarnego zespołu opieki paliatywnej [7, 28-30]. Samodzielność zawodowa jest ważna dla pielęgniarek [31, 33]. Nowe perspektywy w praktyce pielęgniarskiej przyczyniają się do poprawy jakości świadczonych usług medycznych dzięki skróceniu czasu oczekiwania na leki, zwłaszcza w obszarach wiejskich oddalonych o kilkadziesiąt kilometrów od miejskich aglomeracji. Podobnie przekłada się to na szybsze łagodzenie objawów związanych z postępującą nieuleczalną chorobą oraz poprawę jakości życia pacjentów i ich rodzin w wymiarze holistycznym.

Ograniczenia badania to między innymi niewielka liczba uczestników, która może nie być reprezenta- 
tywna dla pielęgniarek pracujących we wszystkich rodzajach opieki paliatywnej w Polsce, ograniczona liczba pytań oraz tylko jednokrotne wypełnienie kwestionariusza.

\section{Wnioski}

1. Zdecydowana większość ankietowanych pielęgniarek i pielęgniarzy stwierdziła, że możliwość przepisywania leków podnosi prestiż ich zawodu oraz może przyczynić się do poprawy jakości usług medycznych świadczonych przez pielęgniarki i pielęgniarzy.

2. Główne przeszkody w wystawianiu recept przez pielęgniarki i pielęgniarzy to brak dodatkowych gratyfikacji finansowych oraz obawa przed odpowiedzialnością.

3. Pielęgniarki $\mathrm{i}$ pielęgniarze opieki paliatywnej z wykształceniem wyższym częściej biorą udział w kursach mających na celu podnoszenie kwalifikacji w zakresie przepisywania leków i wystawiania recept.

4. Większość respondentów sugerowała rozszerzenie listy leków, które mają prawo przepisywać.

\section{Deklaracja konfliktu interesów}

Autorzy oświadczają, że nie występuje konflikt interesów.

\section{Finansowanie}

To badanie nie zostało sfinansowane.

\section{Piśmiennictwo}

1. Ustawa o zawodach pielęgniarki i położnej z dnia 15 lipca 2011 r. (tj. Dz. U.2020, poz.562 z późn. zm.).

2. Stodolak A. Opinie studentów na temat wypisywania recept przez pielęgniarki. Acta Scholae Superioris Medicinae Legnicensis. 2016; 1(17): 41-57.

3. Labuda D, Chorążewicz M, Labuda D, et al. Kontrakt jako alternatywna forma zatrudnienia pielęgniarek w szpitalu. Probl Piel. 2013; 21(3): 388-396.

4. Rozporządzenie Ministra Zdrowia w sprawie wykazu substancji czynnych zawartych w lekach, środków spożywczych specjalnego przeznaczenia żywieniowego i wyrobów medycznych ordynowanych przez pielęgniarki i położne oraz wykazu badań diagnostycznych, na które mają prawo wystawiać skierowania pielęgniarki i położne z dnia 18 stycznia 2018 r. (Dz. U. 2018, poz.299).

5. Bartosiewicz A, Binkowska-Bury M, Januszewicz $P$, et al. Możliwość przepisywania recept przez pielęgniarki i położne - stan prawny w Polsce i ogólny przegląd sytuacji na świecie. Przegląd Medyczny Uniwersytetu Rzeszowskiego i Narodowego Instytutu Leków w Warszawie. 2015; 13(3): 290-305, doi: 10.15584/przmed.2015.3.9.

6. Rozporządzenie Ministra Zdrowia z dnia 13 kwietnia $2018 \mathrm{r}$. w sprawie recept (Dz. U. 2018, poz.745 z późn. zm.).

7. Binkowska-Bury $M$, Nagórska $M$, Januszewicz $P$, et al. Współczesna wizja pielęgniarstwa w systemie e-zdrowia. Problemy Pielęgniarstwa. 2010; 18(3): 342-347.
8. Fuglewicz A. Nowe uprawnienia pielęgniarek i położnych z perspektywy lekarza. Acta Scholae Superioris Medicinae Legnicensis. 2016; 1(17): 58-67.

9. Bejster I. Opinie na temat ordynowania leków/wypisywania recept w środowisku pielęgniarek. Acta Scholae Superioris Medicinae Legnicensis. 2016; 1(17): 26-40.

10. Bartosiewicz A, Binkowska-Bury M, Marć M, et al. Gotowość pielęgniarek do ordynowania leków i wypisywania recept. Problemy Pielęgniarstwa. 2016; 24(2): 91-97, doi: 10.5603/pp.2016.0015.

11. Fong J, Buckley T, Cashin A, et al. Nurse practitioner prescribing in Australia: A comprehensive literature review. Aust Crit Care. 2017; 30(5): 252-259, doi: 10.1016/j. aucc.2016.11.003, indexed in Pubmed: 27913033.

12. Wainwright A, Klein T, Daly C, et al. Competency Development to Support Safe Nurse Practitioner Prescribing of Controlled Drugs and Substances in British Columbia. Policy Polit Nurs Pract. 2016; 17(3): 125-135, doi: 10.1177/1527154416665099, indexed in Pubmed: 27572237.

13. Gielen SC, Dekker J, Francke AL, et al. The effects of nurse prescribing: a systematic review. Int J Nurs Stud. 2014; 51(7): 1048-1061, doi: 10.1016/j.ijnurstu.2013.12.003, indexed in Pubmed: 24398118.

14. Ziegler L, Bennett MI, Mulvey M, et al. Characterising the growth in palliative care prescribing 2011-2015: Analysis of national medical and non-medical activity. Palliat Med. 2018; 32(4): 767-774, doi: 10.1177/0269216317739805, indexed in Pubmed: 29130384.

15. Ryan-Woolley BM, McHugh GA, Luker KA, et al. Prescribing by specialist nurses in cancer and palliative care: results of a national survey. Palliat Med. 2007; 21(4): 273-277, doi: 10.1177/0269216307079047, indexed in Pubmed: 17656402.

16. Ziegler L, Bennett M, Blenkinsopp A, et al. Non-medical prescribing in palliative care: a regional survey. Palliat Med. 2015; 29(2): 177-181, doi: 10.1177/0269216314557346, indexed in Pubmed: 25501312.

17. Quinn B, Lawrie I. Developing nurse independent prescribing in a specialist palliative care setting. Int J Palliat Nurs. 2010; 16(8): 401-405, doi: 10.12968/ijpn.2010.16.8.401, indexed in Pubmed: 20852516.

18. O'Rourke T, Kirk J, Duff E, et al. A survey of nurse practitioner controlled drugs and substances prescribing in three $\mathrm{Ca}$ nadian provinces. J Clin Nurs. 2019; 28(23-24): 4342-4356, doi: 10.1111/jocn.15008, indexed in Pubmed: 31318988.

19. Kiliańska D, Gaworska-Krzemińska A (ed.). Wdrażanie uprawnień do przepisywania leków przez pielęgniarki. Uaktualniony przegląd praktyki przepisywania leków przez pielęgniarki na świecie. Polskie Towarzystwo Pielęgniarskie 2011. http://www.ptp.na1.pl/pliki/nurse_prescribing/Nurse\%20prescribing_PL\%2002.01.2012.pdf (12.01.2020).

20. Binkowska-Bury M, Bartosiewicz A, Marć M, et al. Nowe ustawodawstwo dotyczące możliwości samodzielnego ordynowania leków i wystawiania recept przez pielęgniarki w Polsce: poglądy lekarzy podstawowej opieki zdrowotnej. Medycyna Rodzinna. 2016; 19(2): 47-54.

21. Binkowska-Bury M, Bartosiewicz A, Marć M, et al. Opinia pacjentów Podstawowej Opieki Zdrowotnej na temat ordynowania wybranych leków i wystawiania recept przez pielęgniarki. Hygeia Public Health. 2016; 51(2): 161-170.

22. Ustawa $z$ dnia 31 marca 2020 r. o zmianie niektórych ustaw w zakresie systemu ochrony zdrowia związanych z zapobieganiem, przeciwdziałaniem i zwalczaniem COVID-19 (tj. Dz.U.2020, poz. 567 z późń. zm.).

23. Dominiak I, Grabowska H, Gaworska-Krzemińska A. Ordynowanie leków i wypisywanie recept. Przewodnik dla pielęgniarek i położnych. Edumetriq, Sopot 2017. 
24. Pędzyński B, Pędzyński B. Siostro ja tylko po receptę. Menedżer Zdrowia. 2016(4-5): 74-75.

25. Ustawa z dnia 28 kwietnia 2011 r. o systemie informacji w ochronie zdrowia (tj. Dz.U.2019, poz.408 z póź. zm.).

26. Ustawa z dnia 1 marca 2018 r. o zmianie niektórych ustaw w związku z wprowadzeniem e-recepty (tj. Dz.U. 2018, poz. 697).

27. Ustawa z dnia 19 lipca 2019 r. o zmianie niektórych ustaw w związku z wdrażaniem rozwiązań w obszarze e-zdrowia (tj. Dz.U.2019, poz.1590).

28. Drela K. Pacjenci, a e-zdrowie. Zeszyty Naukowe Uniwersytetu Szczecińskiego. Studia Informatica. 2010; 25: 115-126.

Załącznik. Kwestionariusz wykorzystany w badaniach Kwestionariusz

Charakterystyka badanej grupy

Wiek

$\square \quad 20-30$ lat
$\square \quad 31-40$ lat
$\square \quad 41-50$ lat

Więcej niż 51 lat

Wykształcenie:

$\square$ Średnie (liceum medyczne, medyczna szkoła zawodowa)

$\square$ Wyższe pierwszego stopnia — licencjat pielęgniarstwa

$\square$ Wyższe drugiego stopnia - magister pielęgniarstwa

$\square$ W trakcie studiów magisterskich — magister pielęgniarstwa

Wykształcenie wyższe w ramach innego kierunku studiów:

$\square$ Tytuł magistra na kierunku

\section{Ukończone kształcenie podyplomowe:}

Specjalizacja z zakresu

Kurs kwalifikacyjny z zakresu

Inny rodzaj kursu

Doświadczenie zawodowe w opiece paliatywnej:

$\square<5$ lat

$\square$ 6-10 lat

$\square$ 11-15 lat

$\square$ 16-20 lat

$\square$ 21-25 lat

26-30 lat

$>30$ lat

Miejsce zamieszkania:

$\square$ Miasto

Wieś
29. Antczak A. Zastosowanie telepielęgniarstwa w praktyce pielęgniarki neurologicznej. Piel Neurol Neurochir. 2013; 3: 130-134.

30. Kiliańska D, Grabowska H, Gaworska-Krzemińska A. E-zdrowie wprowadzenie do informatyki w pielęgniarstwie. PZWL, Warszawa 2018.

31. De Walden-Gałuszko K, Kaptacz A. Pielęgniarstwo opieki paliatywnej. PZWL, Warszawa 2017.

32. Boruń T. Rola pielęgniarki w opiece paliatywnej i hospicyjnej - opis przypadku Adama. Piel Zdr Publ. 2011; 1(3): 289-295.

33. Łuczak J, Kotlińska-Lemieszek A. Opieka paliatywna/hospicyjna/medycyna paliatywna. Now Lek. 2011; 80(1): 3-15.

Jednostka organizacyjna zatrudniająca w opiece paliatywnej:

$\square$ Hospicjum domowe/zespół domowej opieki paliatywnej

Poradnia opieki paliatywnej

$\square$ Hospicjum stacjonarne/oddział opieki paliatywnej

1. Czy Pana/Pani zdaniem uzyskanie uprawnień do wypisywania recept podnosi prestiż zawodu pielęgniarki?

$\square$ Tak

Nie

2. Czy ukończył(a) Pan/Pani kurs specjalistyczny: Ordynowanie leków i wypisywanie recept dla pielęgniarek, pielęgniarzy i położnych?

$\square$ Tak

$\square$ Nie

W trakcie kursu

W trakcie studiów magisterskich na kierunku pielęgniarstwo

3. Czy w ramach swojej praktyki pielęgniarskiej wystawia Pan/Pani recepty? (Jeżeli posiada Pan/Pani takie uprawnienia)

Tak

$\square$ Nie

4. Czy Pana/Pani zdaniem uprawnienia do wystawiania recept przez pielęgniarki, pielęgniarzy i położne przyczyniają się do poprawy jakości świadczeń medycznych?

Tak

$\square \mathrm{Nie}$

$\square$ Nie mam zdania

5. Czy Pana/Pani zdaniem możliwość wypisywania recept przez pielęgniarki, pielęgniarzy i położne zwiększa zaufanie pacjentów do tych zawodów?

$\square$ Tak

Nie

Nie mam zdania 
6. Czy możliwość wystawiania recept i kontynuowania leczenia jest przydatna w pracy pielęgniarki w opiece paliatywnej?

$\square$ Tak

$\square$ Nie

7. Czy bierze Pan/Pani również udział w warsztatach, konferencjach i szkoleniach związanych $z$ wypisywaniem recept i na bieżąco uzupełnia swoją wiedzę w tym zakresie?

$\square$ Tak

Nie

8. Czy korzysta Pan/Pani z aplikacji ułatwiających i usprawniających wypisywanie recept? (np. dr Widget, Pharmindex, Empendium)

$\square$ Tak

$\square \mathrm{Nie}$

$\square$ Nie znam takich aplikacji

9. W jakiej formie wystawia Pan/Pani recepty?

Recepta elektroniczna/e-recepta

$W$ formie papierowej/gotowe druki recept

Wydruk z komputera

10.Czy w ramach Pana/Pani praktyki zawodowej przepisuje Pan/Pani wyroby medyczne i wystawia na nie zlecenia?

$\square$ Tak

Nie

11.Dla kogo wystawia Pan/Pani recepty? (można wybrać więcej niż jedną odpowiedź)

$\square$ Pro auctore/dla siebie

$\square$ Pro familia/dla rodziny

$\square$ Dla podopiecznych

Na zlecenie lekarza

Nie wystawiam recept

12. Czy otrzymał(a) Pan/Pani dodatkowe gratyfikacje finansowe za wystawianie recept?

$\square$ Tak

$\square$ Nie

13. Czy kiedykolwiek spotkał(a) się Pan/Pani w aptece $z$ odmową realizacji recepty wystawionej przez pielęgniarkę/pielęgniarza?

$\square$ Tak

$\square \mathrm{Nie}$
Jeżeli tak, jaki był powód takiej odmowy (można wybrać więcej niż jedną odpowiedź)

$\square$ Braki formalne w recepcie wystawionej przez pielęgniarkę/pielęgniarza

$\square$ Niewystarczająca wiedza aptekarza na temat uprawnień pielęgniarek/pielęgniarzy do wystawiania recept

Receptę wystawiono poza zakresem refundacji (odpłatność 100\% )

Aptekarz odmówił wydania leku

$\square$ Brak wiedzy aptekarza na temat wykazu leków objętych zakresem uprawnień pielęgniarek/pielęgniarzy i położnych do ich przepisywania

14.Czy wykaz przepisywanych przez Pana/Panią leków jest wystarczający?

Tak

Nie

$\square$ Które leki Pana/Pani zdaniem powinny zostać objęte samodzielną ordynacją przez pielęgniarki/pielęgniarzy w opiece paliatywnej (proszę wymienić)

15.Jakie przeszkody napotykają pielęgniarki/pielęgniarze w wypisywaniu recept? (można wybrać więcej niż jedną odpowiedź)

$\square$ Niewystarczająca wiedza na temat wypisywania recept

Obawa przed odpowiedzialnością

Trudności w komunikacji w zespole interdyscyplinarnym

Brak dodatkowych gratyfikacji finansowych

Uważam, że wystawianie recept jest obowiązkiem lekarza

Nieufność pacjentów względem pielęgniarek

Brak czasu na kontakt z pacjentem

Moim zdaniem jest to dodatkowe obciążenie w pracy 